\title{
8. CRETACEOUS SUBTROPICAL WEATHERING FOLLOWED BY COOLING AT 60 $\$$ LATITUDE: THE MINERAL COMPOSITION OF SOUTHERN KERGUELEN PLATEAU SEDIMENT, LEG 1201
}

\author{
Mary Anne Holmes ${ }^{2}$
}

\begin{abstract}
Kaolinite, goethite, minor hematite, and gibbsite were found in fluvial upper Lower Cretaceous basal sediment from the Southern Kerguelen Plateau, Sites 748 and $750,55^{\circ} \mathrm{S}$ latitude. This mineral assemblage, derived from the weathering of basalt, indicates near-tropical weathering conditions with high orographic rainfall, at least $100 \mathrm{~cm}$ per year. The climate deteriorated by the Turonian or Coniacian, as indicated by the decline in kaolinite content of this sediment.

The Upper Cretaceous sediment at Site 748 consists of $200 \mathrm{~m}$ of millimeter-laminated, sparsely fossiliferous, wood-bearing glauconitic siltstone and claystone with siderite concretions deposited on a shelf below wave base. Some graded and cross beds indicate that storms swept over the shelf and reworked the sediment. Overlying this unit is $300 \mathrm{~m}$ of intermittently partly silicified, bryozoan-inoceramid-echinoderm-rich glauconitic packstones, grainstones, and wackestones. The dominant clay mineral in both units is identical to the mineral composition of the glauconite pellets: randomly interstratified smectite-mica. The clay fraction has a higher percent of expandable layers than the mineral of the glauconite pellets, and the clay of the underlying subunit has a higher percentage of expandable layers than the clay of the carbonate subunit. Potassium levels mirror these mineral variations, with higher $\mathrm{K}$ levels in minerals that have a lower percentage of expandable layers. The decrease in expandability of the mineral in the upper subunit is attributed to diagenesis, the result of higher porosity.
\end{abstract}

\section{INTRODUCTION}

Ocean Drilling Program (ODP) Leg 120 sailed to the Kerguelen Plateau in the southern Indian Ocean and recovered Cretaceous sediment at three sites (Fig. 1). The Kerguelen Plateau, the conjugate feature to Broken Ridge, is divided into northern and southern regions at approximately $55^{\circ} \mathrm{S}$ latitude (Fig. 2; Schlich, 1975; Houtz et al., 1977). The deepest sedimentary basin in the southern region is the Raggatt Basin (Fig. 2), which contains $2.5-3 \mathrm{~km}$ of sediment fill (Schlich, Wise, et al., 1989). The Raggatt Basin initially formed by either the subsidence of an oceanic-island-type structure or by an oceanic plateau created by excessive volcanism at or near the axis of an oceanic ridge. At the end of the Late Cretaceous, the western part of the basin was uplifted and normal faulting occurred, which may correspond to the breakup of the Southern Kerguelen Plateau and the Diamantina Fracture Zone (Schlich, Wise, et al., 1989). From that time to the present, the basin filled with pelagic chalk followed by calcareous and diatomaceous oozes.

The purpose of this study is to examine in detail the mineral composition and sedimentary structures of nonpelagic Cretaceous sediment from Sites 748 and 750 in order to learn more about paleoclimate and environments of deposition during the early history of the Southern Kerguelen Plateau. Pelagic sediment from these sites and Site 747 contained so little terrigenous detritus that unequivocal identifications could not be made. Site 748 lies in the western part of the Raggatt Basin and Site 750 lies in the eastern part of the Raggatt Basin (Fig. 2).

\footnotetext{
${ }^{1}$ Wise, S. W., Jr., Schlich, R., et al., 1992. Proc. ODP, Sci. Results, 120: College Station, TX (Ocean Drilling Program).

206 Bessey Hall, Geology Department, University of Nebraska-Lincoln, Lincoln, NE 68588-0340, U.S.A.
}

\section{Stratigraphic Summary}

The following summary of the stratigraphy of Cretaceous sediment recovered from the Kerguelen Plateau is taken from shipboard observations recorded in Schlich, Wise, et al. (1989).

\section{Site 748}

The Cretaceous sediment at Site 748 was divided into three lithologic subunits (Fig. 3). In the upper subunit, designated lithologic Subunit IIIA, the dominant sediment component is bioclastic debris (see "Frontispiece," this volume). The bioclasts are alternately dominated by bryozoans, inoceramid prisms and pieces, and echinoderm debris (see "Frontispiece"). An almost complete irregular echinoid was observed at the top of Core $120-748 \mathrm{C}-31 \mathrm{R}$, indicating this sediment underwent little or no transport before being deposited. Red algal fragments (see "Frontispiece") indicate that the water depth was quite shallow, in the range of tens of meters. Other bioclastic components include abundant unbroken foraminifers (see Quilty, this volume), partly recrystallized radiolarians, sponge spicules, echinoderm spines, and coccoliths (see Watkins, this volume). Glauconite pellet content ranges from $2 \%$ to $10 \%$ (based on smear slide analysis), but higher concentrations were observed in a few cores: Cores $120-748 \mathrm{C}$ 56R and -53R (to $30 \%$ ), -48R (to 65\%), and -27R (to 55\%).

This subunit is intermittently partly silicified by chalcedony (Plate 1, Fig. 1). Chalcedony fills pore space locally and encloses glauconite-filled, pyrite-enclosed fossils (Plate 1, Figs. 1-3). Cemented portions range from over $3 \mathrm{~m}$ thick (all of Core $120-748 \mathrm{C}-37 \mathrm{R}$ ) to $10 \mathrm{~cm}$ or possibly less (Core $120-748 \mathrm{C}-47 \mathrm{R})$. The partly silicified layers appear as a very light gray in core photos (Schlich, Wise, et al., 1989). Zeolites are not reported in the shipboard descriptions of this lithologic subunit. The contact between this subunit and underlying Subunit IIIB was not recovered.

Subunit IIIB consists of $206 \mathrm{~m}$ of glauconitic siltstone with minor glauconitic claystones and sandstones (Fig. 3). In the lower $100 \mathrm{~m}$, there are siderite nodules and concretions and 


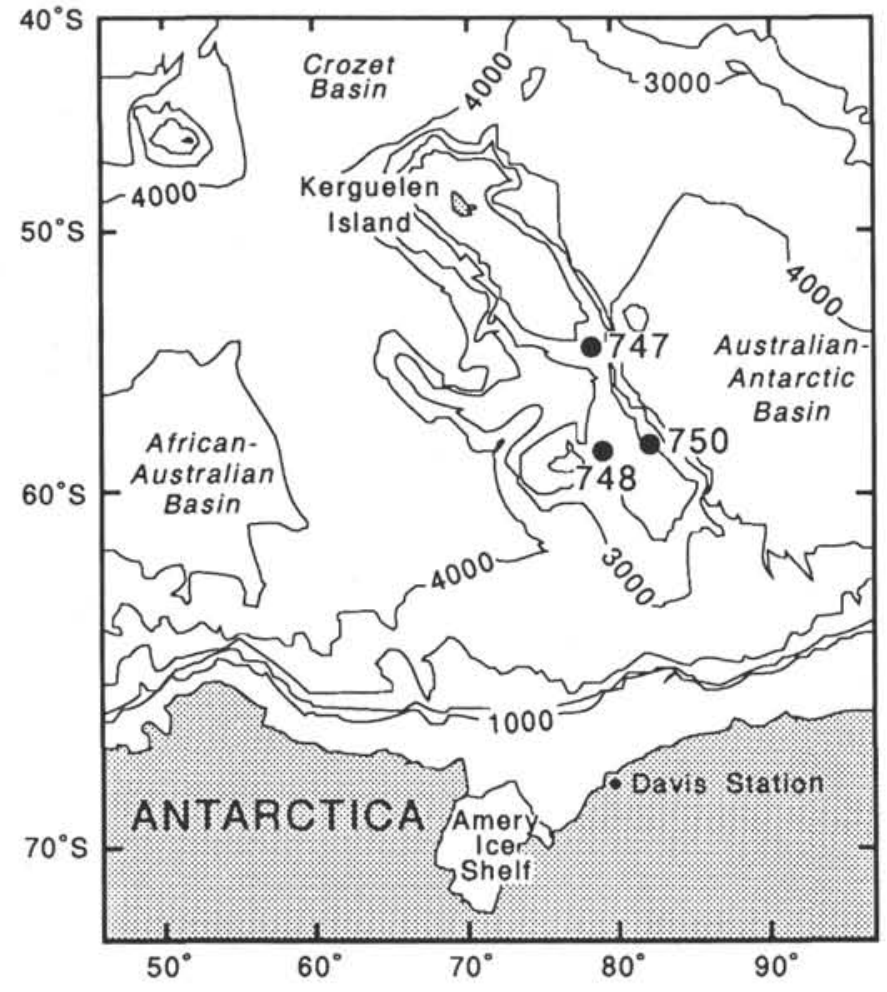

Figure 1. Location of drilling sites, Legs 119 and 120. Contours are in meters.

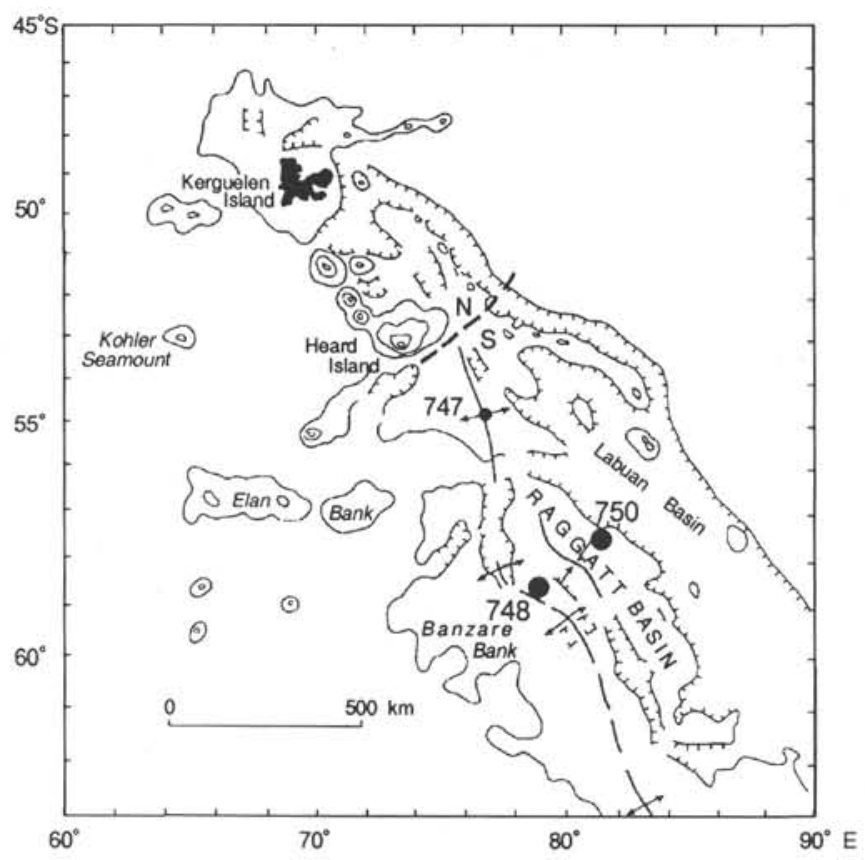

Figure 2. Structural elements of Kerguelen Plateau, including location of Raggatt Basin.

minor amounts of charcoal. The glauconite pellet content, as estimated from smear slides, ranges from $10 \%$ to $50 \%$ of the sediment. The remainder of the sand-size sediment is plagioclase $(<5 \%)$, unidentified altered grains (up to $50 \%$ ), and opaque minerals. Throughout most of this subunit (Cores $120-748 \mathrm{C}-64 \mathrm{R}$ through $-78 \mathrm{R}$ ), the sediment is finely laminated on a millimeter scale. The laminae are commonly disrupted by siderite concretions or subparallel burrows, from $1 \mathrm{~mm}$ to 2 $\mathrm{cm}$ thick. In at least one part of each core, the laminae are almost completely obliterated by bioturbation, and the sediment appears massive (see "Frontispiece"). Many burrows are filled with clay and/or with siderite. Cross laminae and graded, centimeter-thick beds, often with mollusc debris (see "Frontispiece"), appear in Cores 120-748C-70R through $-74 \mathrm{R}$. Pyritized wood was observed in Cores 120-748C-71R through -78R. Zeolites are preserved in Cores 120-748C-76R through $-63 \mathrm{R}$, generally as $5 \%$ of the sediment (based on smear slide analysis). Zeolite laths are especially abundant in Cores $120-748 \mathrm{C}-70 \mathrm{R},-69 \mathrm{R}(15 \%)$, -64R (to $30 \%$ ), and -63R (to $20 \%)$.

Subunit IIIB grades downward to Subunit IIIC, a 1.2-m-thick basalt cobble conglomerate. The clasts include rounded basalt cobbles and broken fragments of molluscs jumbled with sparse grains of glauconite pellets and other bioclastic debris (see "Frontispiece"). At $900 \mathrm{~m}$ below seafloor (mbsf), an alkalibasalt flow was recovered. The cobbles of Subunit IIIC are derived from this flow. Below the basalt flow, a broken flapper valve prevented the recovery of any more sediment at Hole $748 \mathrm{C}$. However, stuck to the bottom hole assembly (BHA) was a bucketful of drilling chips that the core-starved sedimentologists examined in some detail. Most of the chips appeared to be downhole cavings of brown to dark green sediment with glauconite pellets, some with siderite veins. New sediment types that were observed include a pink, highly weathered vesicular basalt, black claystone devoid of fossils and glauconite pellets, and red clay and siltstone. The black claystone appears massive; the red sediment is laminated or massive.

\section{Site 750}

Time constraints required that we spot-core at Site 750 . Three cores of nonpelagic Cretaceous sediment were recovered over an $80-\mathrm{m}$ interval. Black marly chalk and calcareous chalk, some of which is cemented to limestone, were recovered in Core 120-750B-11W (Fig. 3). This sediment is partly laminated and partly burrowed. In Core 120-750B-12W, a very dark grayish brown, massive clayey siltstone was recovered. This sediment is mottled gray and red. No bedding is evident, but the sediment can be broken into pedlike clods with the back of a penknife. Charcoal is scattered throughout the core, but there is no evidence of roots or burrowing. The sand-size sediment is dominantly iron-oxide-coated siderite grains, but some quartz, pyrite, and other opaque materials make up to $50 \%$ of the sediment. No fossils, other than the charcoal, were observed.

Dark brown clayey siltstone and silty claystone, with a 50-cm-thick clay-clast conglomerate (see "Frontispiece") was recovered in Core $120-750 \mathrm{~B}-13 \mathrm{~W}$. The clay- and siltstone are generally massive except where centimeter-thick clay layers are interbedded with more silty layers in part of Section $120-750 \mathrm{~B}-13 \mathrm{~W}-1$ and in the core catcher. The conglomerate is crudely cross-stratified. Abundant charcoal occurs in this core, both dispersed and as several millimeter- to centimeterthick layers (see "Frontispiece"). The clay clasts are bright red, much like the drilling chips from the BHA at Hole $748 \mathrm{C}$, or pea green, pink, light to dark brown, and white to gray. The pink and white to gray clasts are clay-replaced basalt and feldspar, respectively. The brown clasts are the same colors as the enclosing sediment. In the next core, a highly weathered basalt was recovered with a red siltstone fragment above it. Throughout the Cretaceous section at Site 750, no glauconite pellets were observed. However, spot-coring may have missed such sediment. 


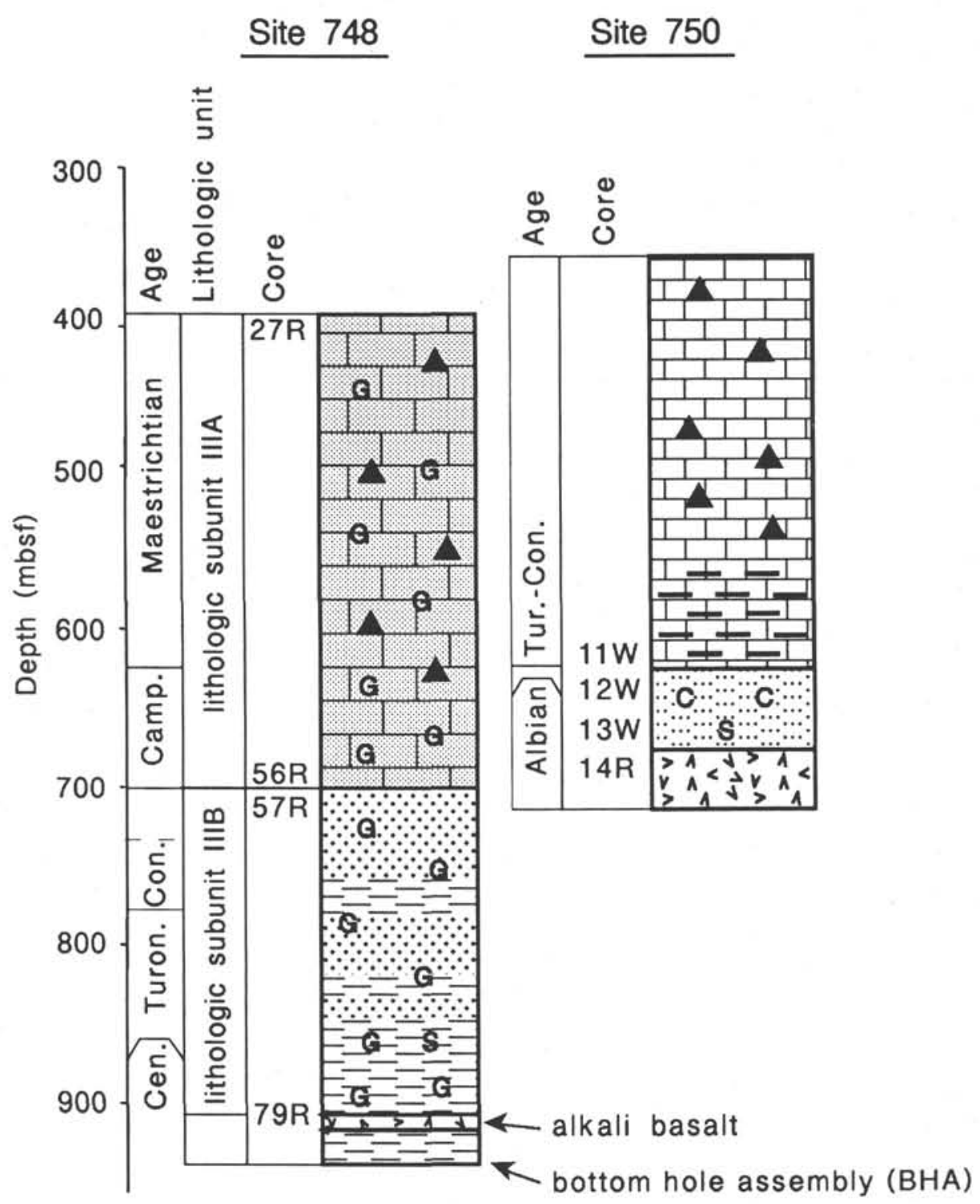

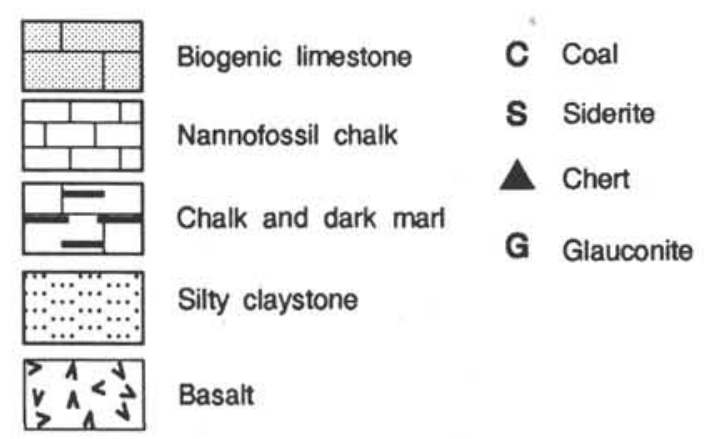

Figure 3. Lithostratigraphy of Cretaceous sediment recovered during drilling at Sites 747, 748, and 750. 


\section{METHODS}

Samples were gently disaggregated in a mortar with distilled water and finger pressure, then sieved through a $64-\mu \mathrm{m}$ screen to remove the coarse fraction. Samples that tested positive for carbonate were treated with $1 \mathrm{~N} \mathrm{HCl}$. These and all samples were washed with distilled water followed by centrifugation three or more times as necessary to achieve dispersion of the clay. The clay was separated by pipette withdrawal after standard settling times (e.g., Lewis, 1984) into $<2-,<1-$, and $<0.5-\mu \mathrm{m}$-size fractions. Size separates were prepared by filtration onto acetate membrane filters with $0.45-\mu \mathrm{m}$ openings, then transferred to glass slides as oriented mounts (Pollastro, 1982).

Sample mounts were X-rayed by means of a Philips APD3720 X-ray diffractometer (XRD) using copper $\mathrm{K} \alpha$ radiation at $40 \mathrm{kV}$ and $20 \mathrm{~mA}$. Samples were scanned untreated from $2^{\circ}$ to $65^{\circ} 2 \theta$; after treatment with ethylene glycol $\left(65^{\circ} \mathrm{C}\right.$ over vapor overnight) from $2^{\circ}$ to $35^{\circ} 2 \theta$; and from $2^{\circ}$ to $15^{\circ} 2 \theta$ after heating to $350^{\circ} \mathrm{C}$ for $3 \mathrm{hr}$.

Mineral identifications were made after Biscaye (1965). Nomenclature for the expandable clay is after the recommendations of Ransom and Helgeson (1989). The percentage of expandable layers was made by comparison with published calculated diffraction patterns (Reynolds, 1980) and by calculation of the 17-10 $\AA$ saddle to $17 \AA$ peak ratio (Rettke, 1981). Identification of silica minerals is after Jones and Segnit (1971). Clinoptilolite was identified by its having survived overnight heating to $500^{\circ} \mathrm{C}$ (Mumpton, 1960).

Oriented mounts and fracture sections were examined using a JEOL Model T330 scanning electron microscope (SEM) equipped with a Kevex energy dispersive spectral analyzer (EDS) for chemical composition.

\section{RESULTS}

\section{Site 748}

\section{Subunit IIIA}

Subunit IIIA at Site 748 has a higher sand content than Subunit IIIB (Fig. 4). The sand-size sediment is dominantly carbonate bioclasts and glauconite pellets (Fig. 5) with pyrite. The fine fraction (silt + clay) is composed of silica, clinoptilolite, and a 10/17 $\AA$ (ethylene glycol) mineral (Fig. 6). Silica occurs as amorphous opal-A, opal-CT, and quartz (Fig. 7). In thin section, silica also appears as chalcedony (Plate 1, Fig. 2). Clinoptilolite (Figs. 6 and 7) is present in $<0.5 \mu \mathrm{m}$ to sand-size fractions and was detected in both lithologic subunits (Cores $120-748 \mathrm{C}-27 \mathrm{R}$ through $-49 \mathrm{R},-53 \mathrm{R},-55 \mathrm{R}$ through $-68 \mathrm{R}$, and $-70 \mathrm{R}$ through $-72 \mathrm{R}$ ).

The only clay mineral detected in Subunit IIIA samples is a $10 / 17 \AA$ (ethylene glycol) clay (Fig. 8). The chemical composition $(15 \%-40 \% \mathrm{Fe})$ indicates this is a nontroniteglauconite (Table 1). The high iron content of the clay is also indicated by the absence of a 002/003 peak at $5 \AA$ (Reynolds, $1980)$. There is less of this mineral in the $<2-\mu \mathrm{m}$ fraction of Subunit IIIA than in Subunit IIIB samples, as indicated by the area of the ethylene glycol-treated (001) peak (Fig. 9). The percentage of expandable layers in this mineral increases with increasing depth (Figs. 8 and 10). This is further verified by the higher $\mathrm{K}$ content in Subunit IIIA clay (Table 2). This mineral is very similar to that which composes the glauconite pellets (Bitschene et al., this volume), except that the clay tends to have a higher percentage of expandable layers than the mineral composing the glauconite pellets. The percent of expandable layers ranges from $50 \%$ to $60 \%$ in Subunit IIIA

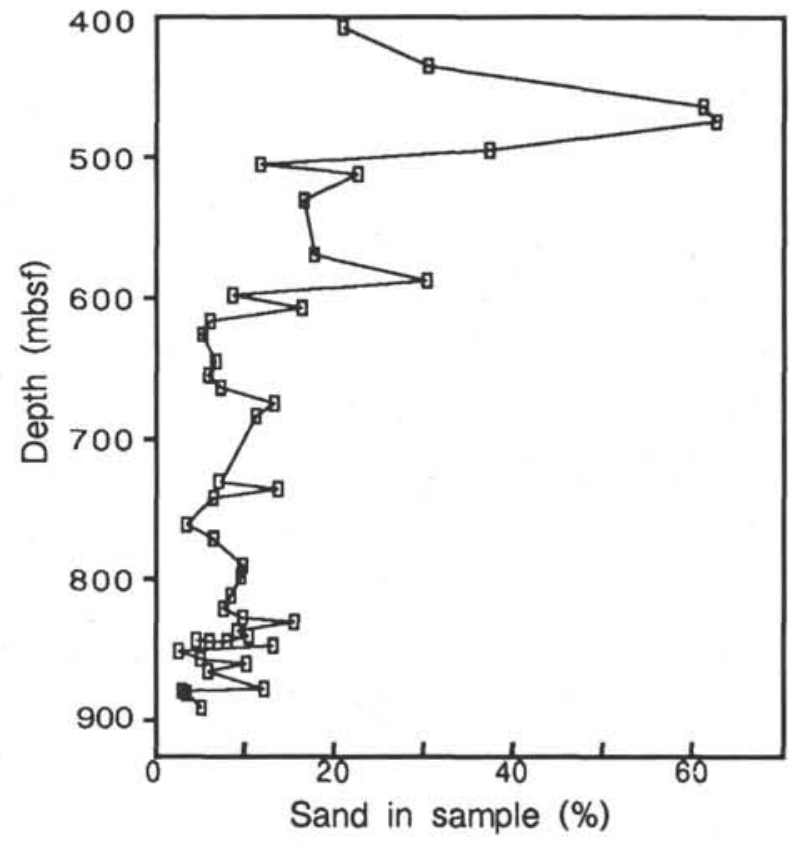

Figure 4. Percentage of sand in sediment vs. depth, Hole $748 \mathrm{C}$.

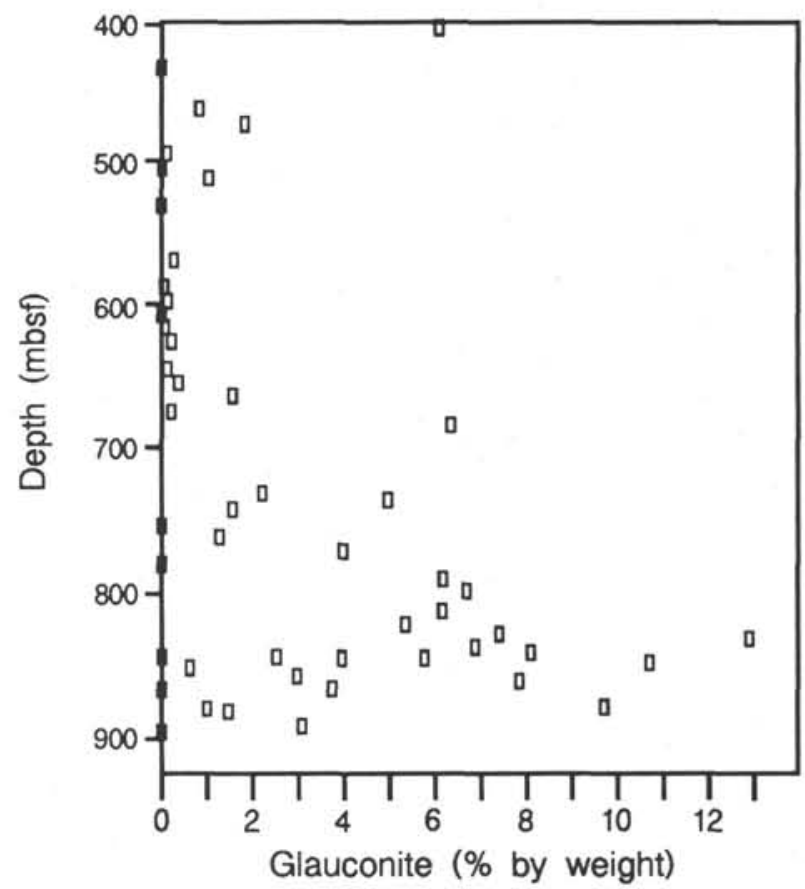

Figure 5. Percentage of glauconite in sediment vs. depth, Hole $748 \mathrm{C}$.

sediment. Plagioclase was detected as a minor component in this lithologic subunit.

\section{Subunit IIIB}

There is less sand in Subunit IIIB than in Subunit IIIA (Fig. 4 ), and it contains only rare bioclasts. The sand is dominantly glauconite pellets (Fig. 5), with some intervals having dominant "altered grains," and all with a small component of pyrite, ferruginous clasts, and charcoal or brown woody material in the lower $100 \mathrm{~m}$. The "altered grains" were described as clear and isotropic, with yellow material of 


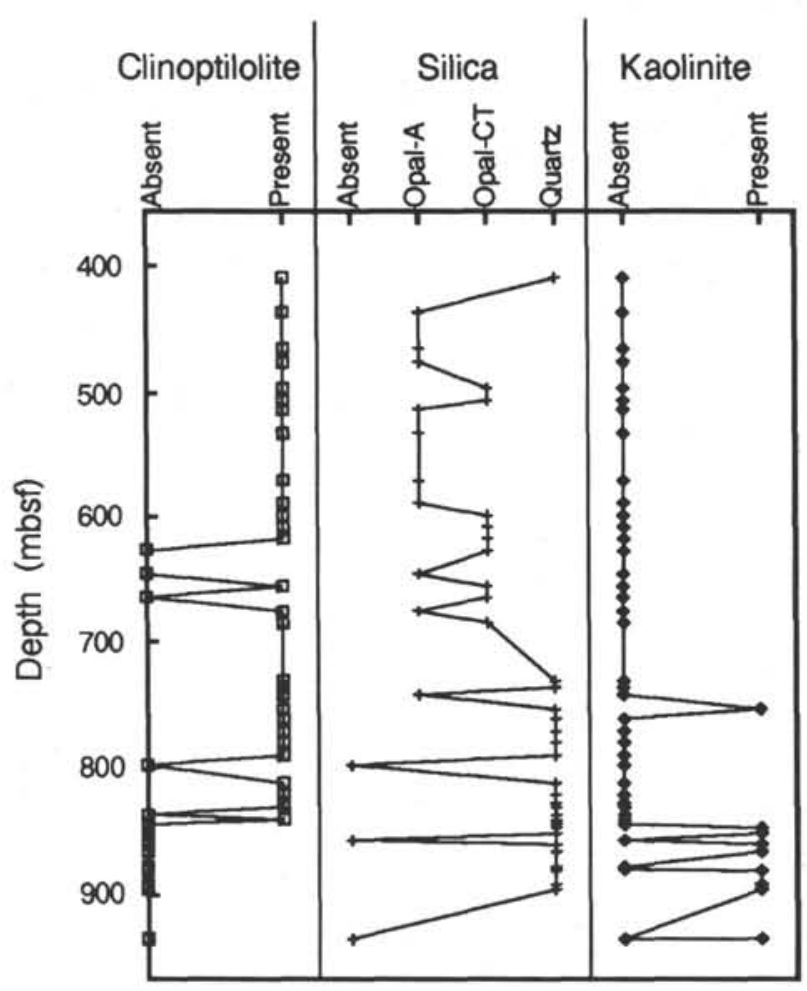

Figure 6. Presence of clinoptilolite and silica as opal-A, opal-CT, or quartz, and kaolinite in Cretaceous sediment, Hole 748C.

medium birefringence in the interior (Schlich, Wise, et al., 1989). These altered grains were handpicked from the sand fraction for this study, crushed, and examined by X-ray diffraction. The results indicate that these are quartz grains with interiors of clinoptilolite (Fig. 11). The amorphous signal between the two quartz peaks (Fig. 11) indicates that amorphous silica is also present. The angular outlines of these grains indicate little or no transport, which, with amorphous silica, indicates a diagenetic origin.

The dominant component of the fine fraction is a $10 / 17 \AA$ (ethylene glycol) clay (Figs. 8 and 10). The percentage of expandable layers of this mineral in the lower subunit ranges from $50 \%$ to $70 \%$ (Fig. 10). Over all the samples examined, the percentage of expandable layers of this clay increases downhole. The strength of this correlation is indicated by a correlation coefficient of $R=0.720$. In addition, the $\mathrm{K}$ content of clay is lower in this lithologic subunit (Table 1). Clinoptilolite is present in most samples to Core $120-748 \mathrm{C}-73 \mathrm{R}$, but was not detected in samples from cores below this (Fig. 7). Only one sample contains opal-A, and there is no evidence of silica cementation in this subunit. All other samples contain quartz or no silica minerals (Fig. 7). A new component detected in Subunit IIIB samples is kaolinite (Figs. 7 and 8, Samples $120-748 \mathrm{C}-74 \mathrm{R}-2,77-79 \mathrm{~cm}$, and $-74 \mathrm{R}-5,22-24 \mathrm{~cm}$ ). It forms a small part of the fine fraction in samples from Cores 120-748C64R, -74R, and -76R through -79R.

\section{Bottom Hole Assembly Sediment}

The black claystone and glauconite pellet-rich sediment from the BHA have the same mineral composition as the sediment of Subunit IIIB: 10/17 $\AA$ (ethylene glycol) clay. These pieces may be downhole cavings, as they look like sediment recovered in Subunits IIIA and IIIB. The red siltand claystone drilling chips from the BHA have a mineral composition identical to that of the Lower Cretaceous sedi- ment of Hole 750B: kaolinite, goethite, and a trace of hematite (Figs. 11 and 12). Not a trace of smectite was observed in the red clay- and siltstone drilling chips. This distinct mineral composition indicates this sediment was not recovered while drilling Subunits IIIA and IIIB. It seems unlikely that this sediment was missed entirely while drilling; it probably comes from sediment below the alkali-basalt flow.

The sediment is much affected by diagenesis, as indicated by the presence of glauconite pellets, abundant pyrite, some in framboids, clinoptilolite, siderite concretions and nodules, and opal-CT.

\section{Hole 750B}

Not enough clay could be extracted from pelagic chalk samples (Cores $120-750 \mathrm{~B}-2 \mathrm{~W}$ to $-10 \mathrm{~W}$ ) for analysis, indicating this area received almost no terrigenous detritus from the late Coniacian through the Maestrichtian. Aside from calcite, the only detectable mineral is clinoptilolite. Upper Cretaceous marly chalk from Core $120-750 \mathrm{~B}-11 \mathrm{~W}$ contains only smectite.

The sand fraction of Lower Cretaceous sediment at Site 750 ranges from $<1 \%$ to $20 \%$ by weight and is dominated by siderite with ferruginous matter and clay included. The siderite was dissolved in hot $\mathrm{HCl}$ and the residue examined under binocular microscope and with the XRD. The dominant component in the residue is white to gray and internally grainy, with an angular outline. The XRD pattern for these grains indicates they are composed of microcrystalline quartz (chert) with kaolinite and siderite. Some of the gray grains contain abundant black inclusions similar to the clay pebbles of the clay-pebble conglomerate. In samples from Core 120$750 \mathrm{~B}-12 \mathrm{~W}$, sand-size components also include pyrite, isotropic vesicular tubules, abundant charcoal, and angular grains that appear to be volcanic glass. In Core $120-750 \mathrm{~B}-13 \mathrm{~W}$, there is charcoal, some of which is pyritized, and abundant brown herbaceous material with cell structures clearly visible. Francis and Coffin (this volume) have studied the herbaceous material in detail.

The mineral composition of the fine fraction of the Lower Cretaceous sediment in Cores $120-750 \mathrm{~B}-12 \mathrm{~W}$ and $-13 \mathrm{~W}$ is like that of the red and green drilling chips in the BHA of Hole 748C (Fig. 12 and Table 2). It consists of kaolinite, goethite, and, in some samples, hematite. Traces of smectite were found only in the weathered basalt (Fig. 12), but even in these samples, kaolinite and goethite are the dominant minerals. In a sample from the soft-pebble conglomerate of Core 120$750 \mathrm{~B}-13 \mathrm{~W}$, gibbsite $\left(\mathrm{Al}[\mathrm{OH}]_{3}\right)$ is present (Fig. 12).

\section{DISCUSSION}

Climatic Implications: Wet and Warm to Wet and Cool

The oldest sediment (early Albian; Mohr and Gee, this volume) contains gibbsite, kaolinite, goethite, and hematite. Gibbsite is the end product of extreme weathering (e.g., Velde, 1985 , p. 55), wherein silica is removed (desilication) after all basic cations have been leached away. The presence of gibbsite in this sediment is highly significant in light of the evidence that no continental crust forms the Kerguelen Plateau and that paleomagnetic results indicate that the plateau has not moved from its present position $\left(55^{\circ} \mathrm{S}\right.$ latitude) since its formation (Schlich, Wise, et al., 1989). Normally, smectite forms in soils weathered from basalt because of the high concentrations of $\mathrm{Mg}$ and $\mathrm{Fe}$ released from the basalt. A modern example is the Nohili clay of Kauai Island, Hawaii, U.S.A. The smectite content of this soil is $75 \%$ (Foote et al., 1976).

Under more intense weathering conditions, $\mathrm{Mg}$ is leached away from soils generated over basalt and smectite does not 

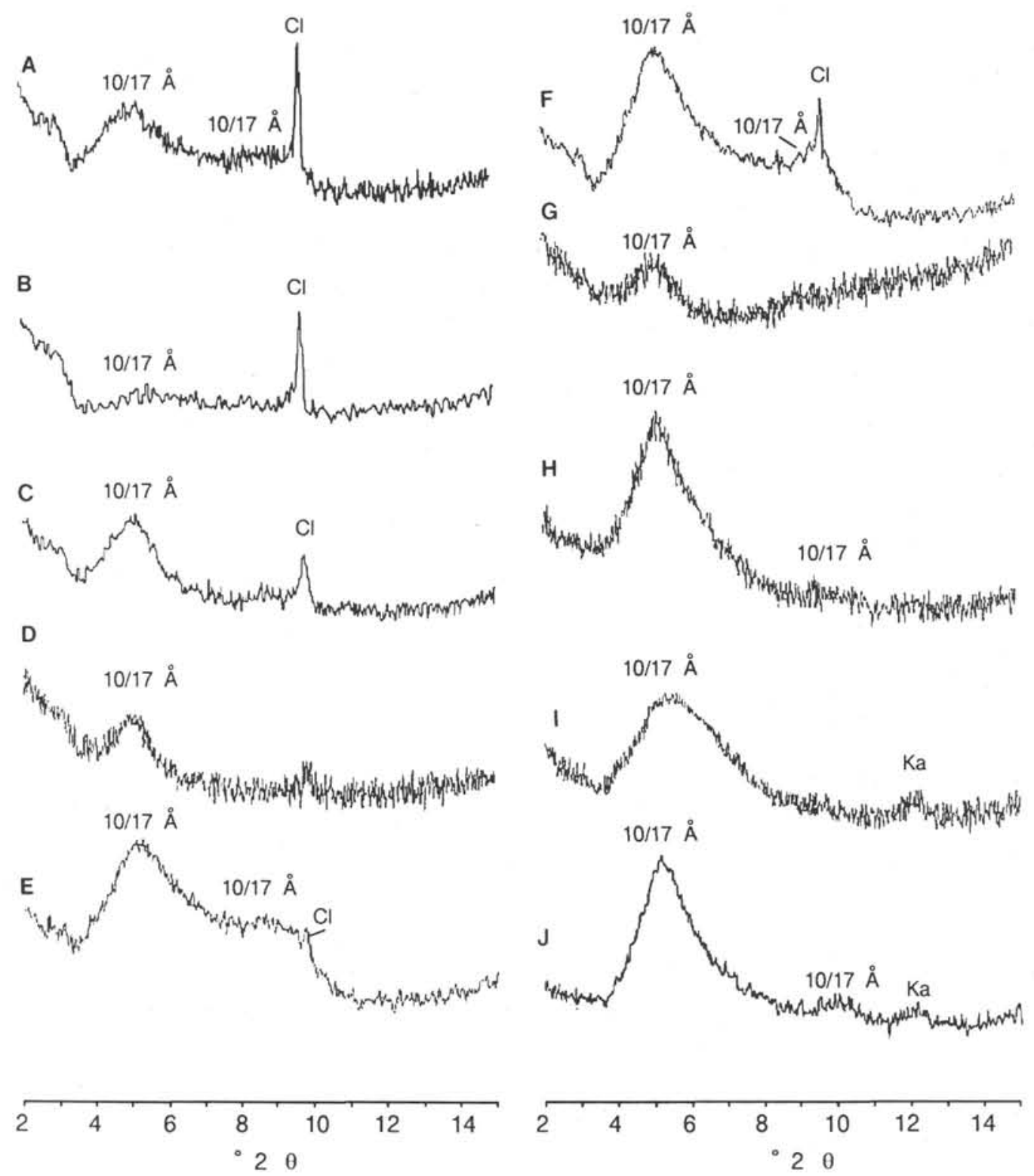

Figure 7. Selected X-ray diffractograms of the $<0.5-\mu \mathrm{m}$-size fraction of Cretaceous sediment, Hole 748C. A. Sample 120-748C-27R-1, 129-131 cm. B. Sample 120-748C-37R-CC. C. Sample 120-748C-47R-1, 90-93 cm. D. Sample 120-748C-55R-2, 110-112 cm. E. Sample 120-748C-56R-2, 46-47 cm. F. Sample 120-748C-64R-2, 93-94 cm. G. Sample 120-748C-69R-1, 83-87 cm. H. Sample 120-748C-73R-6, 88-90 cm. I. Sample 120-748C-74R-2, $77-79 \mathrm{~cm}$. J. Sample $74 \mathrm{R}-5,22-24 \mathrm{~cm}$. S/I = randomly interstratified $10 / 17 \AA$ clay, $\mathrm{Cl}=$ clinoptilolite, and $\mathrm{Ka}$ $=$ kaolinite.

form. For example, on the windward side of the Hawaiian Islands where rainfall is greater than $50 \mathrm{~cm} / \mathrm{yr}$, kaolinite forms in soils over weathered basalt where drainage is good (Sherman, 1962; Bates, 1962; Foote et al., 1976; Parfitt et al., 1988; Tejedor Salguero et al., 1985). Smectite is more abundant in soils on the leeward sides of the Hawaiian islands where rainfall is less intense, and in swampy areas where drainage is poor (Foote et al., 1976). As rainfall increases above 100 $\mathrm{cm} / \mathrm{yr}$, gibbsite forms. For example, Parfitt et al. (1988) compared four Hawaiian soils and found the highest proportion of gibbsite, $60 \%-70 \%$, in the sand fraction of surface and subsurface horizons in the Hilo soil, which forms where annual rainfall is $300 \mathrm{~cm}$. The presence of gibbsite in Core $120-750 \mathrm{~B}-13 \mathrm{~W}$ indicates that, during the late Early Creta- ceous, rainfall at Site 750 reached or exceeded $100 \mathrm{~cm}$ per year. Rainfall may have been seasonal, but extended periods of freezing weather were not likely. The absence of gibbsite at all other DSDP sites in the Southern and Indian oceans with Aptian-Albian age sediment, and the absence of kaolinite at a number of these DSDP sites (Fig. 13) suggests that local orographic conditions caused higher rainfall over the Southern Kerguelen Plateau.

The loss of silica in the high rainfall regions of Hawaii is accompanied by increased silica levels in the form of pedogenic silcrete downslope. Silcrete may be the source of the chert grains in Core 120-750B-12W.

By the late Turonian (base of Core 120-750B-11W), the only clay mineral in Site 750 sediment is smectite. Kaolinite 


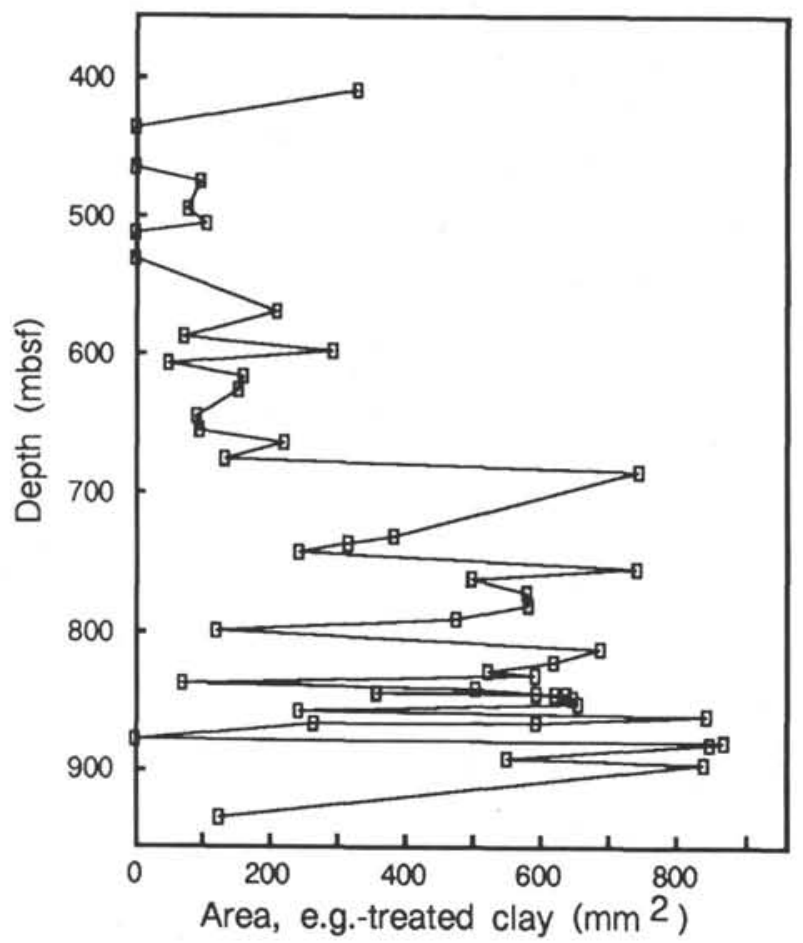

Figure 8. Variation of the area (in $\mathrm{mm}^{2}$ ) of the (001) peak of randomly interstratified nontronite-glauconite with depth, Hole $748 \mathrm{C} . R=$ 0.664 .

disappears from the sediment at Site 748 slightly later: Core $120-748 \mathrm{C}-64 \mathrm{R}$ has the last occurrence of kaolinite and is dated as Coniacian (Mohr and Gee, this volume). The disappearance of kaolinite indicates that the climate over the Kerguelen Plateau cooled and/or rainfall declined from the early Albian to the Turonian. Kaolinite does not recur in younger sediment, indicating that the climate never returned to warm and wet.

Despite climatic deterioration, weathering continued to be intense, as almost no sand-size terrestrial detritus occurs, indicating that chemical and physical weathering were intense enough to weather sand-size particles to oblivion. The released ions were incorporated into glauconite pellets (Bitschene et al., this volume). In addition, the clay continues to show enrichment in $\mathrm{Ti}$, an element that is concentrated in the final stages of weathering. Such a climate might be quite wet but no warmer than temperate. Although monsoonal climates are often invoked to explain the presence of smectitic clay in sediment, it is not necessary where an ample supply of mafic rock serves as the sediment source. Either a cool and temperate or a monsoonal climate could have allowed abundant smectite to form.

Interstratified clays are not commonly reported in soils, but this may be a result of the lack of their differentiation from smectite rather than their absence in soils. At any rate, it is probable that this clay has undergone some diagenesis, as indicated by the increased $\mathrm{K}$ levels in lithologic subunit IIIA sediment. This sediment is much more porous than the underlying Subunit IIIB. More pore water circulating through the sediment would allow the clay to undergo the familiar diagenetic sequence:

$$
\text { smectite }+\mathrm{K} \rightarrow \text { illite }+\mathrm{Si}+\text { (cations }+ \text { water) }
$$

(e.g., Boles and Franks, 1979). During this process, the clay could have released $\mathrm{Al}$ and picked up $\mathrm{Fe}$, a modification of "smectite transformation":

smectite $+\mathrm{Fe}+\mathrm{K} \rightarrow$ illite $+\mathrm{Si}+\mathrm{Al}+$ (cations + water)

(Hower et al., 1976). Released $\mathrm{Al}$ and Si may have recrystallized as the pervasive clinoptilolite

$$
\left.(\mathrm{Na}, \mathrm{K})_{6}\left(\mathrm{Al}_{6} \mathrm{Si}_{30} \mathrm{O}_{22}\right) \cdot 20 \mathrm{H}_{2} \mathrm{O}\right) \text {. }
$$

As both clay and glauconite (in the glauconite pellets) exhibit the same trend of increased $\mathrm{K}$ levels in the upper, more porous lithologic subunit (Bitschene et al., this volume), this process of $\mathrm{K}$ uptake/( $\mathrm{Si}+\mathrm{Al})$ release would have affected both clay and the neoforming glauconite pellets. Such a process may explain why clinoptilolite is observed as inclusions in the glauconite pellets of this sediment, and may further explain high $\mathrm{K}$ levels in glauconite pellets (Bitschene et al., this volume).

\section{Environments of Deposition}

Cretaceous sediment from the Southern Kerguelen Plateau can be divided into four environments of deposition. From oldest to youngest, these are (1) terrestrial sediment represented by the red and green drilling chips from the BHA of Hole $748 \mathrm{C}$ and the fluvial sediment of Cores $120-750 \mathrm{~B}-12 \mathrm{~W}$ and $-13 \mathrm{~W}$; (2) shelf with nearly euxinic conditions represented by Cores $120-748 \mathrm{C}-57 \mathrm{R}$ through $-79 \mathrm{R}$; (3) outer shelf with bioherms of bryozoans, inoceramids, red algae, crinoids, and echinoids represented by Cores $120-748 \mathrm{C}-28 \mathrm{R}$ through $-56 \mathrm{R}$; and (4) pelagic, upper slope represented by Core 120-747C10R-CC, Core 120-750B-11W, Cores 120-750A-15R-3 through $-25 R$, and Core $120-748 C-27 R$.

\section{Site 750}

The organic component of the sediment in Core 120-750B$13 \mathrm{~W}$ contains only terrestrial pollen and spores, indicating that this sediment was deposited in a terrestrial environment (Mohr, this volume). Thus, the claystone and clay-pebble conglomerate are fluvial. The clay pebbles are smooth and round in outline (Plate 1, Fig. 4), indicating they were resistant to disaggregation during transport, possibly by being at least somewhat indurated. Their compressed appearance and interpenetration (Plate 1, Figs. 5 and 6) indicates that they were still soft after deposition and before compaction. The clasts are all $2-4 \mathrm{~mm}$ in diameter in one layer, overlain by a lamina of 1-mm-size clay-pebble clasts. A thin, distorted clay lamina separates the two. This indicates an abrupt decrease in flow regime, and a hiatus between deposition of the pebbles and deposition of the sand-size clay clasts. The high degree of sorting in both layers further indicates that the clay clasts were not emplaced by a debris flow but were fluvial in origin (Schlich, Wise, et al., 1989).

The internal textures of the clasts indicate that they were derived from a weathered volcanic terrain. Some clasts are composed entirely of detrital or pedogenic clay (Plate 1, Fig. 5 ), whereas others have a porphyritic texture, indicating their derivation from weathered volcanic rock (Plate 1, Figs. 4 and 6 ). The high degree of alteration of the porphyritic pebbles may indicate that these were derived from the $C$ horizon of a soil adjacent to the stream. Those composed of only clay could have been derived from a clay-enriched B horizon. The A horizon is coarser in texture and less cohesive than subsurface horizons and is less likely to erode into coherent pebbles. A similar rounding of subsurface soil-derived clay pebbles was 
Table 1. Results of EDX analysis of the $<0.5-\mu m$-size fraction, Hole $748 \mathrm{C}$ sediment.

\begin{tabular}{|c|c|c|c|c|c|c|c|c|c|}
\hline $\begin{array}{l}\text { Leg, hole, } \\
\text { core, section }\end{array}$ & $\begin{array}{l}\text { Depth } \\
\text { (mbsf) }\end{array}$ & $\underset{(\%)}{\mathrm{Si}}$ & $\begin{array}{c}\mathrm{Al} \\
(\%)\end{array}$ & $\begin{array}{l}\mathrm{Fe} \\
(\%)\end{array}$ & $\begin{array}{l}\mathrm{Mg} \\
(\%)\end{array}$ & $\begin{array}{c}\mathrm{Ti} \\
(\%)\end{array}$ & $\begin{array}{l}\mathrm{Cr} \\
(\%)\end{array}$ & $\underset{(\%)}{\mathrm{K}}$ & $\begin{array}{l}\mathrm{Ca} \\
(\%)\end{array}$ \\
\hline \multicolumn{10}{|l|}{$120-748 \mathrm{C}-$} \\
\hline $30 \mathrm{R}-1$ & 435.6 & 56.5 & 6.73 & 22.8 & 2.75 & 0.80 & ND & 7.47 & 2.89 \\
\hline $30 \mathrm{R}-1$ & 435.6 & 64.0 & 10.7 & 8.25 & 0 & 1.07 & ND & 9.80 & 6.26 \\
\hline $47 \mathrm{R}-1$ & 597.9 & 56.2 & 10.6 & 14.5 & 0 & 4.74 & ND & 8.73 & 5.20 \\
\hline $47 \mathrm{R}-1$ & 597.9 & 57.3 & 9.87 & 14.7 & 0 & 4.93 & ND & 8.63 & 4.58 \\
\hline $59 \mathrm{R}-1$ & 684.5 & 46.9 & 4.23 & 32.4 & 0 & 1.75 & 0.19 & 11.4 & 3.13 \\
\hline $59 \mathrm{R}-1$ & 684.5 & 47.6 & 2.25 & 24.4 & 0 & 2.27 & ND & 10.3 & 3.25 \\
\hline $59 \mathrm{R}-1$ & 684.5 & 44.1 & 4.86 & 35.9 & 0 & 1.80 & ND & 10.5 & 2.89 \\
\hline $63 R-1$ & 742.4 & 48.6 & 6.24 & 37.3 & 0 & 1.67 & ND & 4.34 & 1.87 \\
\hline $63 \mathrm{R}-1$ & 742.4 & 50.0 & 6.40 & 34.3 & 0 & 1.74 & ND & 5.20 & 2.33 \\
\hline $68 \mathrm{R}-1$ & 790.2 & 43.2 & 7.98 & 39.9 & 0 & 1.88 & ND & 4.19 & 2.89 \\
\hline $68 \mathrm{R}-1$ & 790.2 & 46.1 & 7.74 & 36.3 & 0 & 1.86 & ND & 4.73 & 3.30 \\
\hline $75 R-4$ & 860.0 & 53.7 & 12.5 & 23.4 & 0 & 3.16 & ND & 4.97 & 2.23 \\
\hline $75 R-4$ & 860.0 & 52.8 & 12.94 & 22.7 & 0 & 0.50 & ND & 8.34 & 2.76 \\
\hline $75 R-4$ & 860.0 & 56.1 & 16.38 & 17.7 & 0 & 2.00 & ND & 4.91 & 2.86 \\
\hline
\end{tabular}

Note: ND $=$ not detectable.

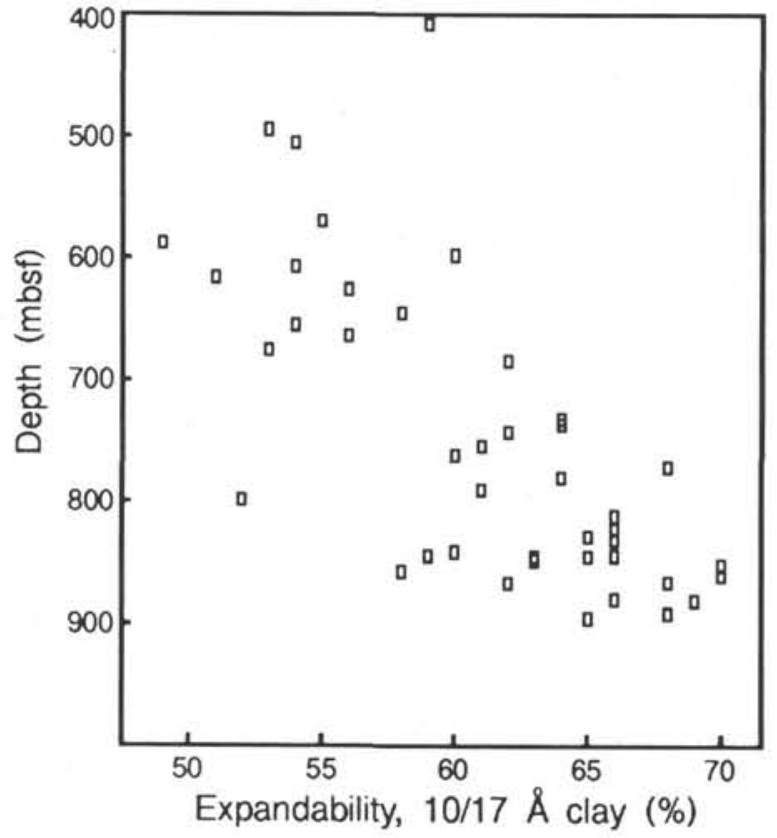

Figure 9. Variation of percent expandable layers in $10 / 17 \AA$ (ethylene glycol) clay, Hole 748C. $R=0.718$.

reported by Joeckel (1987) from the fluvial Dakota Formation of eastern Nebraska. There, paleosols that were the source of clay clasts in channel lags were identified in juxtaposition to the fluvial sediment.

The sediment from Core $120-750 \mathrm{~B}-12 \mathrm{~W}$ may also be terrestrial as it has no glauconite pellets in a region that seems prone to glauconite formation (Bitschene et al., this volume). A pedlike structure and gleylike mottling of the massive clay in this core suggest a paleosol, but the absence of pollen, spores, and any unequivocal rhizoliths leaves this interpretation in doubt. A marginal marine setting, such as a marsh or lagoon, is also possible.

The necessity for spot-coring caused us to miss the transition between terrestrial and marine sediment. By the Turonian, Site 750 lay in the pelagic realm and received marly chalk and nannofossil chalk (see Watkins, this volume). Once marl deposition ceased, this site received very little terrigenous matter until the Oligocene, when icebergs dropped

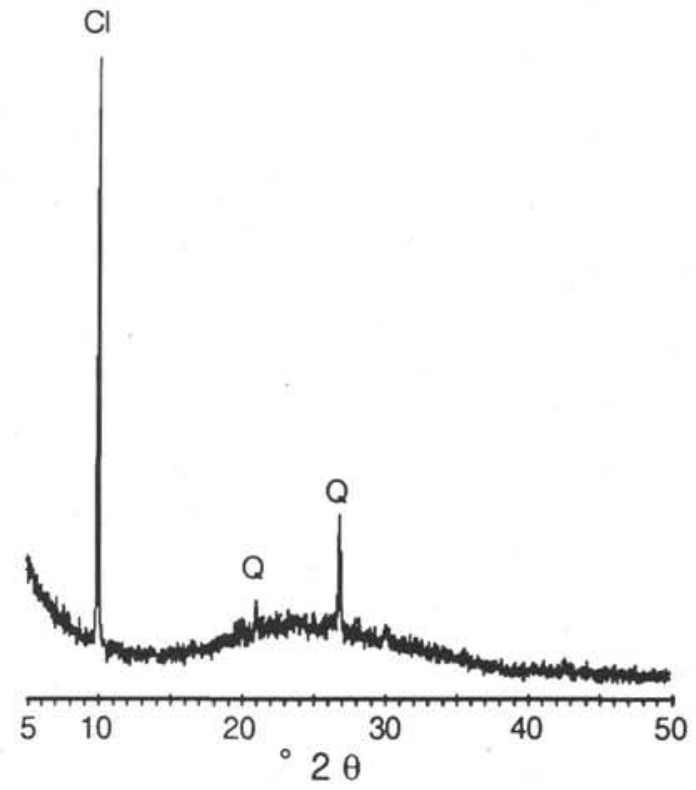

Figure 10. X-ray diffraction results of ground, handpicked "altered grains"' of lithologic Subunit IIIB, Sample 120-748C-68R-1, 75-77 cm. Peak at $8.9 \AA$ is clinoptilolite; peaks at 4.24 and $3.32 \AA$ are from quartz.

debris over the Kerguelen Plateau (Breza and Wise, this volume).

\section{Site 748}

The mineral composition of the red and green drilling chips in the BHA correlates this sediment with the terrestrial Albian sediment of Site 750 . Sometime before or shortly after the alkali-basalt flow of Core 120-748C-79R was emplaced, marine conditions onset at Site 748 . This is indicated by the presence of glauconite pellets and bivalves in the sediment immediately overlying the flow. Subunit IIIB has abundant glauconite pellets, rare bivalves, sporadic burrowing/feeding structures, cross beds, and grading. The absence of fossils, which are so abundant in Subunit IIIA, implies a limiting environmental requirement for most benthic organisms, such as turbid waters or low oxygen level in the water near the 
Table 2. Minerals identified by X-ray diffraction in Cretaceous sediment, Site $\mathbf{7 5 0}$.

\begin{tabular}{|c|c|c|c|c|c|c|c|}
\hline \multirow{2}{*}{$\begin{array}{l}\text { Core, section, } \\
\text { interval }(\mathrm{cm})\end{array}$} & \multirow{2}{*}{$\begin{array}{l}\text { Depth } \\
\text { (mbsf) }\end{array}$} & \multirow[b]{2}{*}{ Lithotype } & \multicolumn{3}{|c|}{ Minerals in size fraction } & \multirow[b]{2}{*}{$20 \mu \mathrm{m}$} & \multirow[b]{2}{*}{$40 \mu \mathrm{m}$} \\
\hline & & & $0.5 \mu \mathrm{m}$ & $1.0 \mu \mathrm{m}$ & $2.0 \mu \mathrm{m}$ & & \\
\hline \multicolumn{8}{|l|}{$120-750 \mathrm{~B}-$} \\
\hline $11 \mathrm{~W}-1,15-16$ & 594.75 & Chalk & & Calc & & Sm,Calc & Calc \\
\hline $11 \mathrm{~W}-2,79-81$ & 596.90 & Clay-rich chalk & & Calc & & $\mathrm{Sm}, \mathrm{Calc}$ & Calc \\
\hline $12 W-1,26-29$ & 623.77 & Clayey siltstone & & Ka,Go & $\mathrm{Ka}, \mathrm{Go}, \mathrm{He}$ & $\mathrm{Ka}, \mathrm{Go}, \mathrm{He}, \mathrm{Si}$ & $\mathrm{Ka}, \mathrm{Go}, \mathrm{He}, \mathrm{Si}$ \\
\hline $12 W-1,61-63$ & 624.12 & Clayey siltstone & $\mathrm{Ka}, \mathrm{Go}, \mathrm{He}$ & $\mathrm{Ka}, \mathrm{Go}, \mathrm{He}$ & $\mathrm{Ka}, \mathrm{Go}, \mathrm{He}$ & $\mathrm{Ka}, \mathrm{Go}, \mathrm{He}, \mathrm{Si}$ & $\mathrm{Ka}, \mathrm{Go}, \mathrm{He}, \mathrm{Si}$ \\
\hline $12 W-1,71-73$ & 624.22 & Clayey siltstone & $\mathrm{Ka}, \mathrm{Go}, \mathrm{He}$ & & & $\mathrm{Ka}, \mathrm{Go}, \mathrm{He}, \mathrm{Si}$ & $\mathrm{Ka}, \mathrm{Go}, \mathrm{He}, \mathrm{Si}$ \\
\hline $12 W-2,16-18$ & 625.17 & Clayey siltstone & $\mathrm{Ka}, \mathrm{Go}, \mathrm{He}$ & & $\mathrm{Ka}, \mathrm{Go}, \mathrm{He}, \mathrm{Si}$ & $\mathrm{Ka}, \mathrm{Go}, \mathrm{He}, \mathrm{Si}$ & $\mathrm{Ka}, \mathrm{Go}, \mathrm{He}, \mathrm{Si}$ \\
\hline $12 W-2,70-72$ & 625.71 & Clayey siltstone & $\mathrm{Ka}, \mathrm{Go}, \mathrm{He}$ & & & $\mathrm{Ka}, \mathrm{Go}, \mathrm{He}, \mathrm{Si}$ & $\mathrm{Ka}, \mathrm{Go}, \mathrm{He}, \mathrm{Si}$ \\
\hline $12 W-2,144-146$ & 626.45 & Clayey siltstone & & & $\mathrm{Ka}$ & $\mathrm{Ka}, \mathrm{Go}, \mathrm{He}$ & $\mathrm{Ka}, \mathrm{Go}, \mathrm{He}$ \\
\hline $12 \mathrm{~W}-3,33-35$ & 626.84 & Clayey siltstone & & $\mathrm{Ka}, \mathrm{Go}, \mathrm{He}$ & $\mathrm{Ka}, \mathrm{Go}, \mathrm{He}$ & $\mathrm{Ka}, \mathrm{Go}, \mathrm{He}$ & $\mathrm{Ka}, \mathrm{Go}, \mathrm{He}, \mathrm{Si}$ \\
\hline $12 \mathrm{~W}-3,93-95$ & 627.44 & Clayey siltstone & $\mathrm{Ka}, \mathrm{Go}, \mathrm{He}$ & $\mathrm{Ka}, \mathrm{Go}, \mathrm{He}$ & $\mathrm{Ka}, \mathrm{Go}, \mathrm{He}$ & $\mathrm{Ka}, \mathrm{Go}, \mathrm{He}, \mathrm{Si}$ & $\mathrm{Ka}, \mathrm{Go}, \mathrm{He}, \mathrm{Si}$ \\
\hline $12 \mathrm{~W}-\mathrm{CC}$ & 634.00 & Bedded clayey siltstone & & & $\mathrm{Ka}, \mathrm{Go}, \mathrm{He}$ & $\mathrm{Ka}, \mathrm{Go}, \mathrm{He}, \mathrm{Si}$ & $\mathrm{Ka}, \mathrm{Go}, \mathrm{He}, \mathrm{Si}$ \\
\hline $12 \mathrm{~W}-\mathrm{CC}, 15-17$ & 634.16 & Bedded clayey siltstone & $\mathrm{Ka}$,Go & & $\mathrm{Ka}, \mathrm{Go}, \mathrm{He}$ & $\mathrm{Ka}, \mathrm{Go}, \mathrm{He}, \mathrm{Si}$ & $\mathrm{Ka}, \mathrm{Go}, \mathrm{He}, \mathrm{Si}$ \\
\hline $13 \mathrm{~W}-1,15-16$ & 643.95 & Clayey siltstone & & & $\mathrm{Ka}, \mathrm{Go}, \mathrm{He}$ & $\mathrm{Ka}, \mathrm{Go}, \mathrm{He}, \mathrm{Si}$ & $\mathrm{Ka}, \mathrm{Go}, \mathrm{He}, \mathrm{Si}$ \\
\hline $13 W-1,44-46$ & 644.25 & Clay clast conglomerate & & & & & $\mathrm{Ka}, \mathrm{Go}, \mathrm{He}, \mathrm{Gi}$ \\
\hline $13 W-1,120-122$ & 645.01 & Clayey siltstone & & $\mathrm{Ka}, \mathrm{Go}, \mathrm{He}$ & $\mathrm{Sm}, \mathrm{Ka}, \mathrm{Go}, \mathrm{He}$ & $\mathrm{Ka}, \mathrm{Go}, \mathrm{He}, \mathrm{Si}$ & $\mathrm{Ka}, \mathrm{Go}, \mathrm{He}, \mathrm{Si}$ \\
\hline $13 \mathrm{~W}-2,75-77$ & 646.06 & Clayey siltstone & $\mathrm{Ka}, \mathrm{Go}, \mathrm{He}$ & & & $\mathrm{Ka}, \mathrm{Go}, \mathrm{He}$ & $\mathrm{Ka}, \mathrm{Go}, \mathrm{He}, \mathrm{Si}$ \\
\hline $13 W-2,135-137$ & 646.66 & Clayey siltstone & $\mathrm{Ka}$, Go & & $\mathrm{Ka}, \mathrm{Go}, \mathrm{He}$ & $\mathrm{Ka}, \mathrm{Go}, \mathrm{He}$ & $\mathrm{Ka}, \mathrm{Go}, \mathrm{He}$ \\
\hline $13 W-3,11-13$ & 646.92 & Clayey siltstone & $\mathrm{Ka}, \mathrm{Go}, \mathrm{He}$ & $\mathrm{Ka}, \mathrm{Go}, \mathrm{He}$ & & $\mathrm{Ka}, \mathrm{Go}, \mathrm{He}$ & $\mathrm{Ka}, \mathrm{Go}, \mathrm{He}, \mathrm{Si}$ \\
\hline $13 \mathrm{~W}-\mathrm{CC}, 13-14$ & 654.43 & Clayey siltstone & & & & & \\
\hline $14 \mathrm{R}-1,68-70$ & 672.19 & Basalt & $\mathrm{Sm}, \mathrm{Ka}$ & & & $\mathrm{Ka}, \mathrm{Go}, \mathrm{He}$ & $\mathrm{Ka}, \mathrm{He}$ \\
\hline $14 \mathrm{R}-1,110-111$ & 672.60 & Basalt & $\mathrm{Sm}, \mathrm{Ka}, \mathrm{Go}, \mathrm{He}$ & & $\mathrm{Sm}, \mathrm{Ka}, \mathrm{Go}, \mathrm{He}$ & $\mathrm{Ka}, \mathrm{Go}, \mathrm{He}$ & $\mathrm{Ke}, \mathrm{Go}, \mathrm{He}$ \\
\hline $14 \mathrm{R}-2,8-9$ & 673.80 & Basalt & $\mathrm{Ka}$ & $\mathrm{Sm}, \mathrm{Ka}, \mathrm{Go}$ & $\mathrm{Ka}, \mathrm{Go}$ & $\mathrm{Sm}, \mathrm{Ka}, \mathrm{Go}, \mathrm{He}$ & $\mathrm{Ka}, \mathrm{Go}, \mathrm{He}$ \\
\hline
\end{tabular}

Notes: $\mathrm{Gi}=$ gibbsite, $\mathrm{Go}=$ goethite, $\mathrm{He}=$ hematite, $\mathrm{Ka}=$ kaolinite, $\mathrm{Si}=$ siderite, $\mathrm{Sm}=$ smectite, and $\mathrm{Calc}=$ calcite .

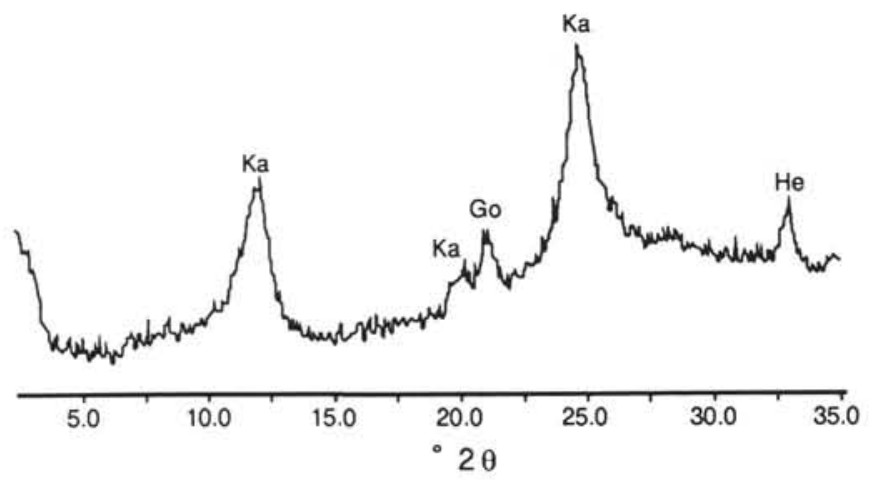

Figure 11. X-ray diffraction results of red and green drilling chips from the bottom hole assembly, Hole $748 \mathrm{C} . \mathrm{Ka}=$ kaolinite, $\mathrm{GO}=$ goethite, and $\mathrm{He}=$ hematite.

sediment-water interface. Most of the sediment occurs in millimeter-thick laminae, which indicates quiet water.

Glauconitic matter tends to form in the middle to outer shelf areas where waters are oxidizing and sediment is near or fully reducing (e.g., McRae, 1972). The presence of abundant glauconite pellets and the absence of fossils indicates bottom waters were oxidizing, but oxygen levels were not high enough to support abundant benthic life. The characteristics of this sediment indicate deposition on a shelf, below the wave base, with occasional storms intense enough to form roughly graded and cross beds.

Between the Coniacian and early Campanian, conditions improved for bottom-dwelling organisms, and bryozoan-inoceramid bioherms developed, with all the other organisms identified, both planktonic and benthic: echinoids, crinoids, red algae, sponges, foraminifers, diatoms, radiolarians, coccoliths, mosasaurs, and fish (Schlich, Wise, et al., 1989). The waters were shallow but oceanic, probably at the mid to outer edge of a shallow shelf. Sedimentation kept pace with subsidence. Between the Maestrichtian and the Paleocene, the plateau rapidly sank to great depths, which precluded bio- herm-formers at all sites (Schlich, Wise, et al., 1989). Very little terrigenous matter reached the plateau after this, as so little noncarbonate residue could be extracted from it. All terrestrial areas of the Southern Kerguelen Plateau disappeared below the sea by the early Paleocene.

\section{SUMMARY AND CONCLUSIONS}

Sedimentation on the Southern Kerguelen Plateau at Site 750 , eastern Raggatt Basin, began during or before the Albian with the formation of soils and development of streams on a volcanic terrain of high relief. The presence of abundant gibbsite in fluvial sediment indicates that temperatures were above freezing for most of the year and that annual rainfall exceeded $100 \mathrm{~cm}$. This tropical to subtropical climate occurred at $55^{\circ} \mathrm{S}$ latitude during the late Early Cretaceous. Although kaolinite has been reported from other DSDP sites in the Indian and Southern oceans, it is only abundant in Aptian-Albian sediment. The absence of gibbsite from all other sites indicates that rainfall may have been enhanced over the Southern Kerguelen Plateau by orographic conditions.

The mineral composition of basal terrestrial sediment at Site 750 allows for the correlation of sedimentary fragments recovered only as drilling chips in the BHA at Site 748 . The ages may not be identical, but the environments of deposition are similar.

The transition to a cooler and/or drier climate occurred between the Turonian and the Coniacian, as indicated by the disappearance of kaolinite from the fine fraction of Site 748 sediment. The dominant clay throughout this and the Campanian-Maestrichtian sequence is similar to that which composes the glauconite pellets, a $10 / 17 \AA$ (ethylene glycol) mineral. In the upper, more permeable lithologic subunit, this clay has a higher $\mathrm{K}$ content and fewer expandable layers, indicating diagenesis has affected this mineral and caused a reduction in expandable layers of smectite. Silica and possibly $\mathrm{Al}$ given off by this process and by dissolution of plagioclase and volcanic glass led to clinoptilolite precipitation.

The glauconitic claystones, siltstones, and mudstones of Subunit IIIB were deposited on an open continental shelf 

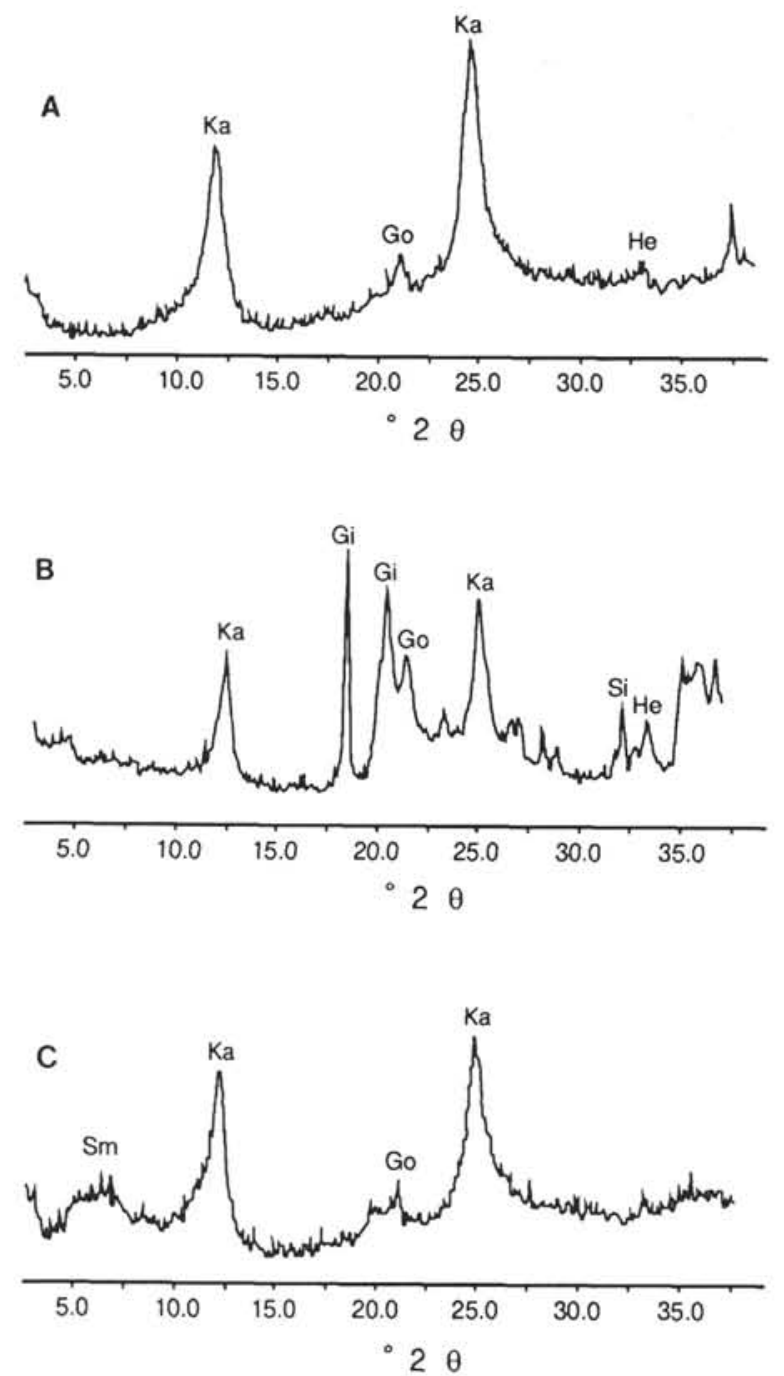

Figure 12. X-ray diffraction results from sediment from Hole 750B. A. Sample 120-750B-12W-CC, $15-17 \mathrm{~cm},<0.5 \mu \mathrm{m}$ fraction. B. Sample 120-750B-13W-1, 51-52 cm, bulk sample. C. Sample 120-750B-14R-1, $110-111 \mathrm{~cm},<2 \mu \mathrm{m}$ fraction (weathered rind of basalt). $\mathrm{Gi}=$ gibbsite, $\mathrm{Go}=$ goethite, $\mathrm{He}=$ hematite, $\mathrm{Ka}=$ kaolinite, $\mathrm{Si}=$ siderite, $\mathrm{Sm}=$ smectite.

below wave base, occasionally disturbed by storms. The oxygen content of the bottom water was too low to support abundant benthic life. This changed by the early Campanian, when a bryozoan-inoceramid-echinoderm-sponge bioherm flourished to form Subunit IIIA.

The volcanoes that formed the Kerguelen Plateau and the life that clung to them provided the only sediment for the fill of the Raggatt Basin. The basalt provided an abundant source of iron, which appears in terrestrial sediment as goethite and hematite and in marine sediment as glauconite pellets and pore fillings, pyrite, and siderite.

\section{ACKNOWLEDGMENTS}

This study was supported by funds from USSAC-JOI. The United States Department of Agriculture-Soil Conservation Service generously allowed the use of their X-ray diffractometer; Mrs. S. Legeros assisted with its operation. Sample preparation was accelerated by T. Dunn, L. Huaibao, and X. Huaibao. Drafting and darkroom help were supplied by $\mathrm{T}$.
Dunn, C. Herbel, H. LaGarry-Guyon, and J. Wegrzyn. EDS analyses were performed by $\mathrm{K}$. Lee; assistance on the SEM was provided by K. Lee and M. Q. Yang. More XRD time was provided by the Materials Science Group of UNL, with assistance by V. Farenya. Thanks to R. L. Hay, S. W. Wise, Jr., A. Palmer-Julson, and an anonymous reviewer for helpful discussions and comments on the manuscript. A special thanks to all the shipboard technical staff of Leg 120.

\section{REFERENCES}

Bates, T. F., 1962. Halloysite and gibbsite formation in Hawaii. 9th Inter. Conf., Clays Clay Minerals, 9:315-328.

Biscaye, P. E., 1965. Mineralogy and sedimentation of recent deepsea clays in the Atlantic Ocean and adjacent seas and oceans. Geol. Soc. Am. Bull., 76:803-832.

Boles, J. R., and Franks, S. G., 1979. Clay diagenesis in Wilcox sandstones of southwest Texas: implications of smectite diagenesis on sandstone cementation. J. Sediment. Petrol., 49:55-70.

Cook, H. E., Zemmels, I., and Matti, J. C., 1974a. X-ray mineralogy data, southern Indian Ocean - Leg 26, Deep Sea Drilling Project. In Davies, T. A., Luyendyk, B. P., et al., Init. Repts. DSDP, 26: Washington (U.S. Govt. Printing Office), 573-592.

1974b. X-ray mineralogy data, eastern Indian Ocean - Leg 27, Deep Sea Drilling Project. In Veevers, J. J., Heirtzler, J. R., et al., Init. Repts. DSDP, 27: Washington (U.S. Govt. Printing Office), 535-548.

Foote, D. E., Hill, E. L., Nakamura, S., and Stephens, F., 1976. Soil survey of the Islands of Kauai, Oahu, Maui, Molokai and Lanai, State of Hawaii. USDA with Univ. of Hawaii.

Gautier, D. L., 1982. Siderite concretions: indicators of early diagenesis in the Gammon Shale (Cretaceous). J. Sediment. Petrol., 52:859-871.

Gottardi, G., and Galli, E., 1985. Natural Zeolites. Berlin (SpringerVerlag), 256-284.

Hoffman, J., and Hower, J., 1979. Clay mineral assemblages as low grade metamorphic geothermometers: application to the thrust faulted Disturbed Belt of Montana, U.S.A. Spec. Publ. Soc. Econ. Paleontol. Mineral., 26:55-79.

Houtz, R. E., Hayes, D. E., and Markl, R. G., 1977. Kerguelen Plateau bathymetry, sediment distribu $\sim$ tion and crustal structure. Mar. Geol., 25:95-130.

Hower, J., Eslinger, E. V., Hower, M. E., and Perry, E. A., 1976. Mechanism of burial metamorphism of argillaceous sediment: mineralogical and chemical evidence. Geol. Soc. Am. Bull., 87:725-737.

Joeckel, R. M., 1987. Paleogeomorphic significance of two paleosols in the Dakota Formation (Cretaceous), southeastern Nebraska. Contrib. Geol., Univ. of WY, 25:95-102.

Jones, J. B., and Segnit, E. R., 1971. The nature of opal. I. Nomenclature and constituent phases. J. Geol. Soc. Aust., 18:57-68.

Lewis, D. W., 1984. Practical Sedimentology: New York (Van Nostrand-Reinhold).

McRae, S. G., 1972. Glauconite. Earth-Sci. Rev., 8:397-440.

Matti, J. C., Zemmels, I., and Cook, H. E., 1974. X-ray mineralogy data, western Indian Ocean - Leg 25, Deep Sea Drilling Project. In Simpson, E.S.W., Schlich, R., et al., Init. Repts. DSDP, 25 : Washington (U.S. Govt. Printing Office), 843-861.

Mumpton, F. A., 1960. Clinoptilolite redefined. Am. Mineral., 45:351-369.

Parfitt, R. L., Childs, C. W., and Eden, D. N., 1988. Ferrihydrite and allophane in four andepts from Hawaii and implications for their classification. Geoderma, 41:223-241.

Pollastro, R. M., 1982. A recommended procedure for the preparation of oriented clay-mineral specimens for X-ray diffraction analysis: modification to Drever's filter-membrane peel technique. OpenFile Rep.-U.S. Geol. Surv., 71-82.

Ransom, B., and Helgeson, H. C., 1989. Correlation of expandability with mineralogy and layering in mixed-layer clays. Clays Clay Miner., 37:189-191.

Rettke, R. C., 1981. Probable burial diagenetic and provenance effects on Dakota Group clay mineralogy, Denver Basin. J. Sediment. Petrol., 51:541-551. 
Reynolds, R. C., 1980. Interstratified clay minerals. In Brindley, G. W., and Brown, G. (Eds.), Crystal Structures of Clay Minerals and their X-Ray Identification. Mineral. Soc. London Monogr., 5:249-303.

Schlich, R., 1975. Structure et âge de l'océan Indien occidental. Mem. Hors Ser. Soc. Geol. Fr., 6:1-103.

Schlich, R., Wise, S. W., Jr., et al., 1989. Proc. ODP, Init. Repts., 120: College Station, TX (Ocean Drilling Program).

Sherman, G. D., 1962. The Ti content of Hawaiian soils and its significance. Soil Sci. Soc. Am. Proc., 16:15-18.

Siesser, W. G., and Bremner, J. M., 1978. X-ray mineralogy of cores from Leg 40, Deep Sea Drilling Project. In Bolli, H. M., and Ryan, W.B.F., et al., Init. Repts. DSDP, 40: Washington (U.S. Govt. Printing Office), 541-548.

Tejedor Salguero, M. L., Mendoza, C. J., Rodriguez Rodrigues, A., and Fernandez Caldas, E., 1985. Polygenesis on deeply weathered Pliocene basalt, Gomera (Canary Islands): from ferrallitization to salinization. Volcan. Soils (Catena Suppl.), 7:131-151.
Varentsov, I. M., Sakharov, B. A., and Eliseeva, T. G., 1983. Clay components of post-middle Jurassic sediments of the southwest Atlantic, Deep Sea Drilling Project, Leg 71: depositional history and authigenic transformations. In Ludwig, W. J., Krashenninikov, V. A., et al., Init. Repts. DSDP, 71: Washington (U.S. Govt. Printing Office), 351-359.

Velde, B., 1985. Clay Minerals: A Physico-Chemical Explanation of Their Occurrence: Amsterdam (Elsevier), Devl. in Sediment. Ser., 40: $52-58$.

Zemmels, I., Harrold, P. J., and Cook, H. E., 1976. X-ray mineralogy data from the Argentine Basin-Leg 36 Deep Sea Drilling Project. In Barker, P. F., Dalziel, I.W.D., et al., Init. Repts. DSDP, 36: Washington (U.S. Govt. Printing Office), 1017-1031.

Date of initial receipt: 15 February 1990

Date of acceptance: 16 October 1990

Ms 120B-140 


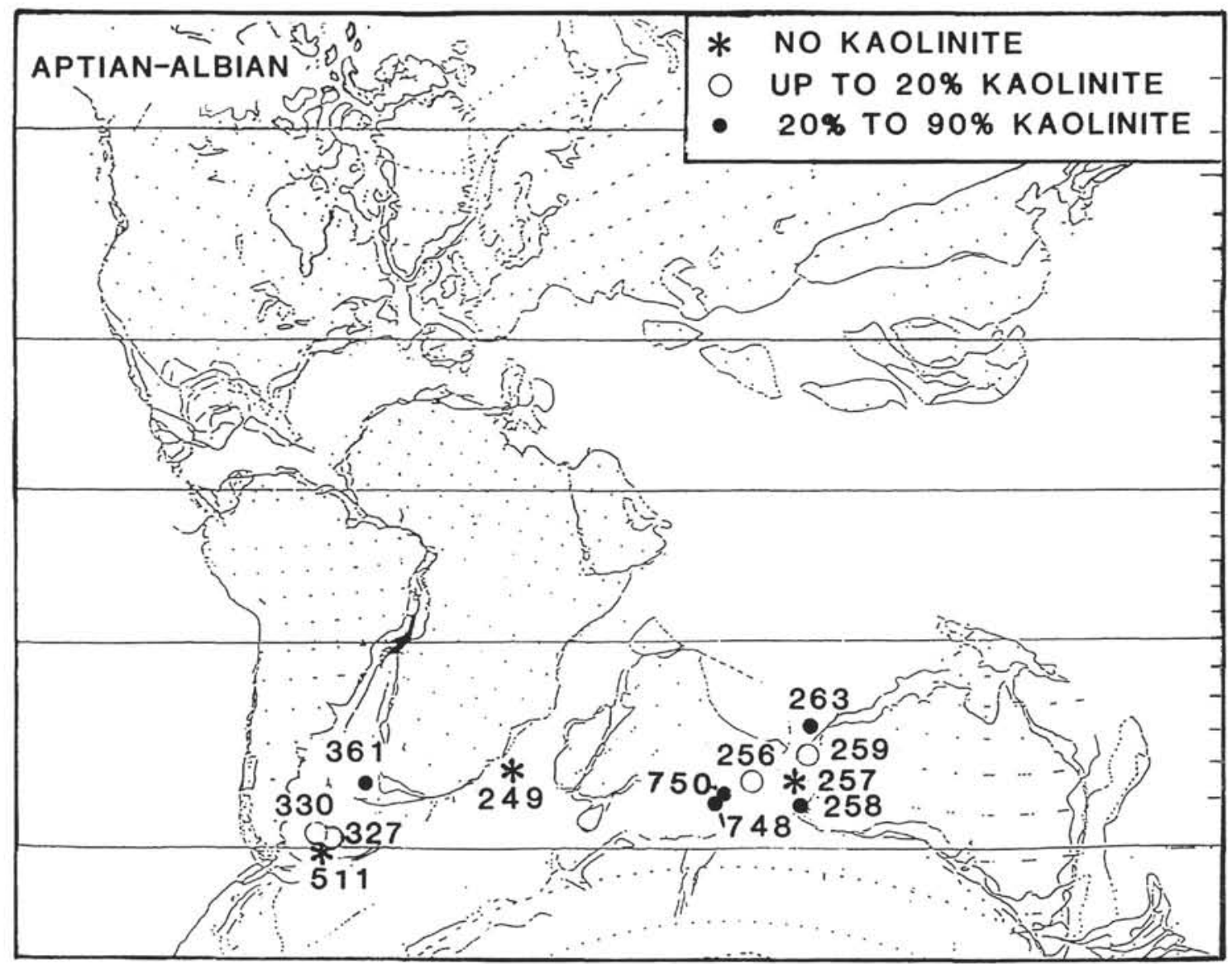

Figure 13. The reconstruction of the Indian Ocean at Magnetic Anomaly M0, $118.7 \mathrm{Ma}$ (after Scotese et al., 1988). Shown are DSDP sites with sediment type and kaolinite presence and abundance. Data from DSDP Site 249 (Matti et al., 1974), from DSDP Sites 256, 257, and 258 (Cook et al., 1974a), from DSDP Sites 259, 260, and 263 (Cook et al., 1974b), from DSDP Sites 327 and 330 (Zemmels et al., 1976), from DSDP Site 361 (Siesser and Bremner, 1978), and from DSDP Site 511 (Varentsov et al., 1983). 


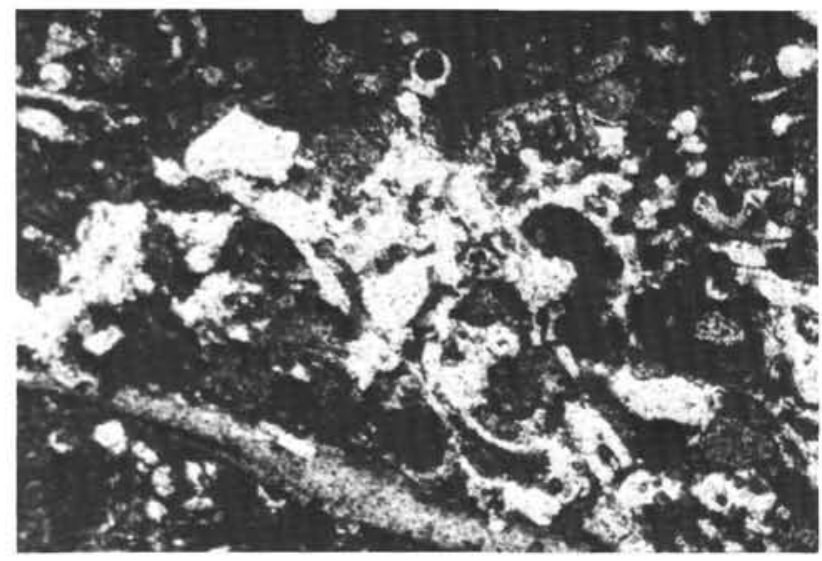

1

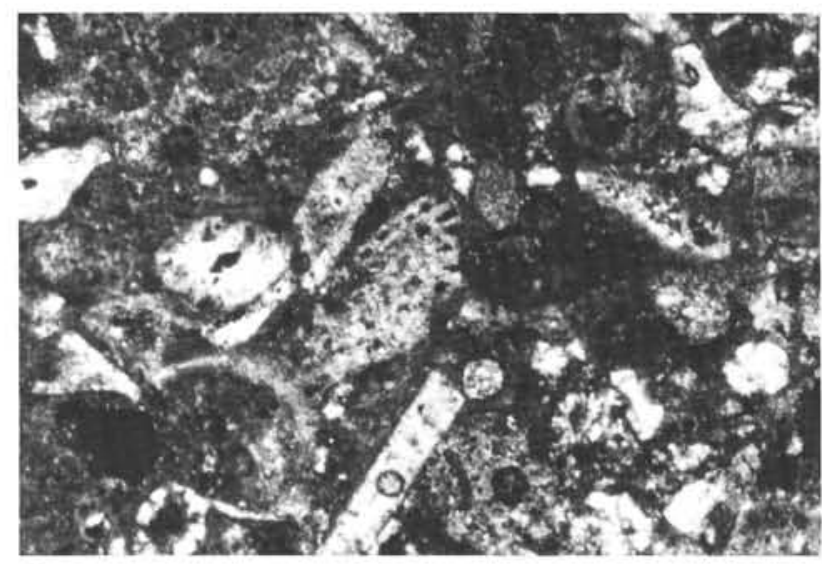

3

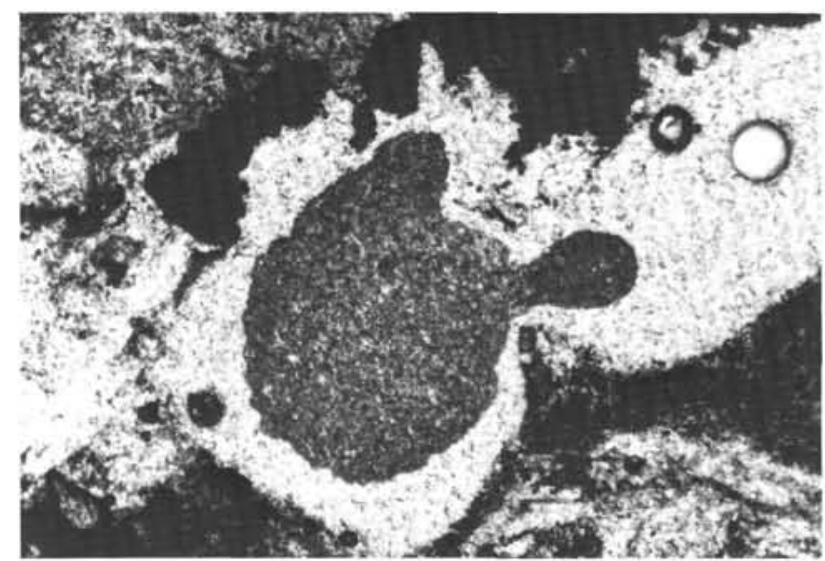

5

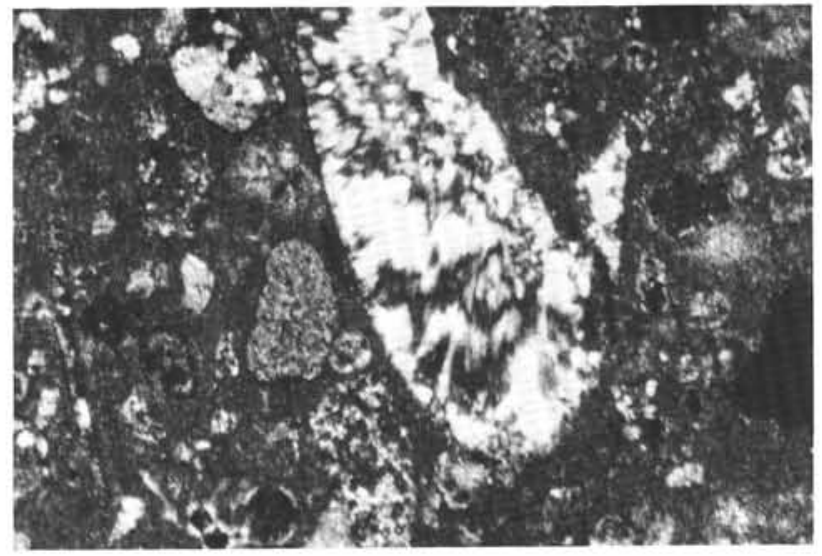

2

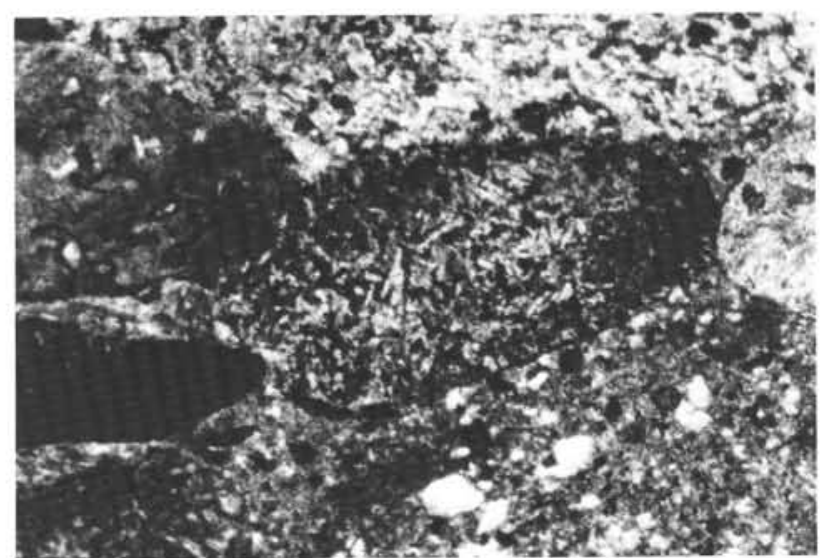

4

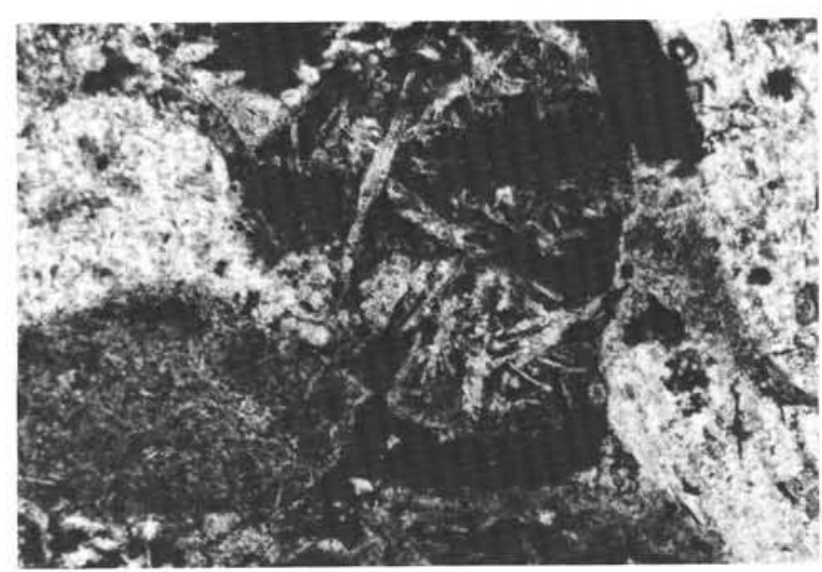

6

Plate 1. Thin section photomicrographs of glauconitic, partly silicified lithologic Subunit IIIA, Hole 748C and of clay clast conglomerate, Sample 120-750B-13W-1, 50-53 cm. 1. Sample 120-748C-30R-2, 22-24 cm. Glauconite fills bryozoan zooecia (center) and echinoid spine cut transversely (lower right), and also occurs as pellets throughout. Chalcedony replaces echinoid spines and bivalve shells. 2. Sample 120-748C-30R-2, 22-24 cm. Chalcedony permeates pore space and envelops glauconite and pyrite-enclosed echinoid spines. Bivalve fragment along lower right is original calcite. 3. Sample $120-748 \mathrm{C}-30 \mathrm{R}-2,22-24 \mathrm{~cm}$. Chalcedony replaces bivalve fragments. A glauconite pellet occurs to the right of the largest bivalve. 4. Rounded clasts with porphyritic texture and rims of iron oxide. 5. Clay clasts showing interpenetration and permeation by iron oxide. 6. Clay clasts with clay interiors and porphyritic interiors interpenetrated before deposition of iron oxide rim cement. 